\title{
Market research to identify commercial viability of buccal tablets based on white clay
}

\section{Investigación de mercados para identificar viabilidad comercial de pastillas para uso bucal a base de arcilla blanca}

GONZÁLEZ-VÁZQUEZ, Isidro*†, ÁNGEL-GARCÍA, Martha Patricia and ARTEAGAITURRARÁN, Raul

Universidad Tecnológica de Jalisco

ID $1^{\text {st }}$ Autor: Isidro, González-Vázquez / ORC ID: 0000-0003-4854-9038, CVU CONACYT ID: 914192

ID $1^{\text {st }}$ Coautor: Martha Patricia, Ángel-García / ORC ID: 0000-0001-6277-603X, CVU CONACYT ID: 280802

ID $2^{\text {nd }}$ Coautor Raul, Arteaga-Iturrarán / ORC ID: 0000-0001-9217-9658, CVU CONACYT ID: 915209

DOI: 10.35429/EJT.2019.5.3.21.23

Received March 30, 2019; Accepted June 20, 2019

\begin{abstract}
About a billion tubes of toothpaste are discarded in landfills every year. It becomes a real environmental problem considering that the package is composed of $75 \%$ plastic and 25\% aluminum. Aware of this, new green brands go on the market with the will to eradicate such waste. The idea is to validate the developing of a toothpaste that is a pill that is used for cleaning teeth that will be mainly clay combined with coconut oil. Making this toothpaste will result on a better dental health as well as taking care of the environment, helping to eliminate plastics. Using clay and coconut oil has prove to destroy of all types of microbes, viruses, bacteria, many of which harm our oral hygiene. Helping to solve the problem of caries that affects 60 to 90 percent of the population by improving their dental hygiene. Survey in a simple of 383 inhabitans was taken in order to Identify areas of commercial opportunity and the willingness of the consumer to purchase oral cleaning tablets.
\end{abstract}

Dental Pills, Market research, Commercial viability

\begin{abstract}
Resumen
Cerca de un billón de tubos de pasta de dientes son desechados en los vertederos cada año. Un verdadero problema ambiental teniendo en cuenta que el envase se compone de un $75 \%$ de plástico y un $25 \%$ de aluminio. Conscientes de esto, nuevas marcas verdes salen al mercado con la voluntad de erradicar tal derroche. Queremos desarrollar una pasta dental que es una especie de pastilla que se emplea para la limpieza de los dientes que será principalmente de arcilla combinada con el aceite de coco. Elaborando esta pasta dental podríamos ayudar a tener una mejor salud dental además de cuidar el medio ambiente ayudando a la eliminación de plásticos, ya que al utilizar arcilla y el aceite de coco que es un poderoso destructor de todo tipo de microbios, virus, bacterias muchas de las cuales perjudican nuestro aseo bucal. De esta manera solucionaremos el problema de las caries que afecta del 60 al 90 por ciento de la población mejorando su higiene dental.
\end{abstract}

Pastillas dentales, Investigación de mercados, Viabilidad comercial

Citation: GONZÁLEZ-VÁZQUEZ, Isidro, ÁNGEL-GARCÍA, Martha Patricia and ARTEAGA-ITURRARÁN, Raul. Market research to identify commercial viability of buccal tablets based on white clay. ECORFAN Journal-Taiwan. 2019, 35: $21-23$

\footnotetext{
* Correspondence to Author (email: igonzalez@utj.edu.mx)

$\dagger$ Researcher contributing first author.
} 


\section{Objetivel}

Identify areas of commercial opportunity and the willingness of the consumer to purchase oral cleaning tablets.

\section{Methodology}

A quantitative study was carried out having a survey applied in the Great Guadalajara Area to a representative sample of 383 surveys of men and women over 18 years with a $95 \%$ confidence level and a margin of error of 5\%. The survey was conducted by simple random subsampling by clusters and random home routes and in squares and shopping centers.

\section{Introduction}

The present project in which students of the Career in Engineering in Development and Business Innovation of the Technological University of Jalisco participated was carried out with the intention of detecting sustainable alternatives in products of daily consumption, in this case the replacement of plastics in the use of Plastics of toothpastes.

It has worked together with students of the Environmental Technology Career, to know the feasibility of producing dental pills.

The market research presented, allows us to know the commercial viability of the product.

\section{Problem Statement}

Brushing your teeth is a highly recommended habit for oral health. However, the pastes that are used cause various environmental impacts on rivers and oceans. Dentifrices carry substances such as micro plastics.

Recent studies indicate that of the 9.5 million tons of plastic annually that are thrown into the oceans between $15 \%$ and $31 \%$ are micro plastics While micro particles have industrial and scientific applications, they are mostly used as abrasives in a variety of cosmetic and personal care products, such as toothpastes and scrubs.

It is intended to develop a toothpaste that is a kind of pill that is used for cleaning teeth that will be mainly clay combined with coconut oil.
Making this toothpaste we could support dental health in addition to taking care of the environment by helping to eliminate plastics, since by using clay and coconut oil it is a powerful destroyer of all types of microbes, viruses, bacteria, many of the which harm our oral hygiene. In this way we will solve the problem of caries that affects 60 to 90 percent of the population by improving their dental hygiene.

\section{Inclusion of Graphs, Figures and Editable Tables}

How many times a day do you brush your teeth?

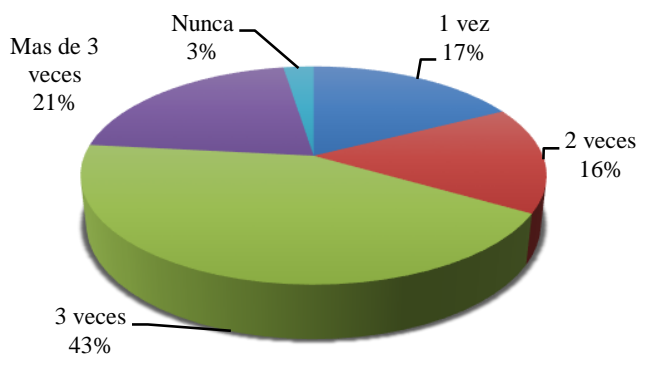

Graphic 1 "Frequency of tooth washing" Source Own elaboration based on survey results July 2019

How often do you buy toothpaste?

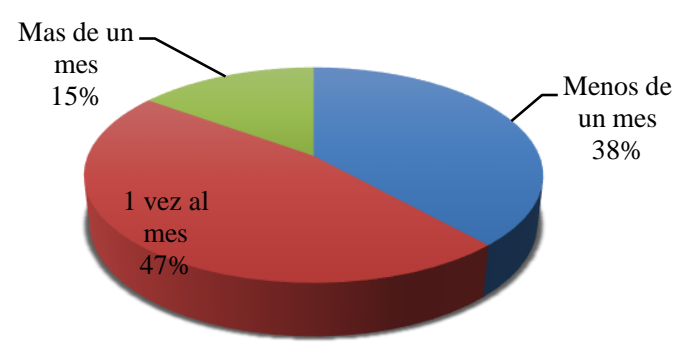

Graphic 2 "Frequency of purchase."

Source Own elaboration based on survey results July 2019

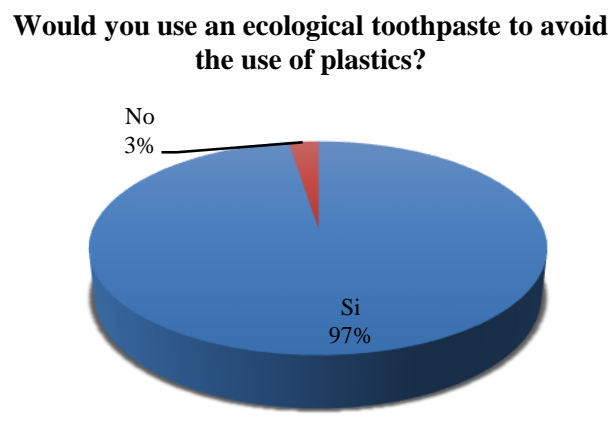

Graphic 3 "Provision of purchase of dental pill" Source Own elaboration based on survey results July 2019 


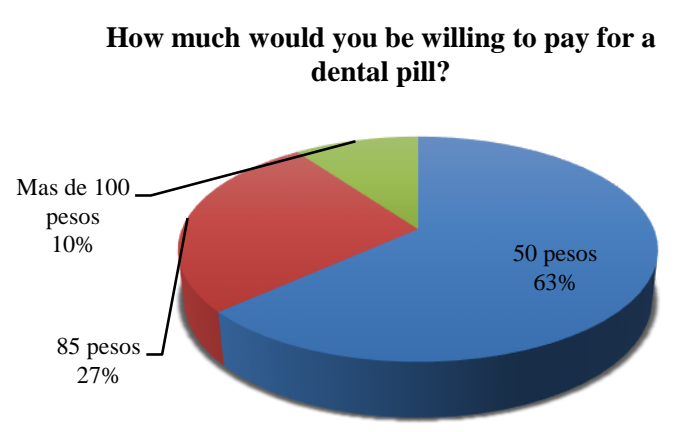

Graphic 3 "Price perceived by the consumer"

Source Own elaboration based on survey results July 2019

\section{Methodology to be developed}

Give the meaning of the variables in linear writing and it is important to compare the criteria used

\section{Results}

As we know, oral hygiene is important as it talks a lot about our person. Similarly, we live in an era in which society is becoming aware of the damage we cause to the environment with the amount of plastic used, under this context we add traditional toothpastes in addition to the amount of chemicals that Ingests our body is necessary to implement alternatives of substitute products to reduce the consumption of chemicals, the use of plastics and thereby help the environment.

According to the results of the surveys carried out in the first instance, the product is accepted, since it is perceived as novel and environmentally friendly, especially in young people although older adults say they continue with the usual toothpastes.

\section{Acknowledgments}

For the present investigation, 8th grade students participated in the design and field work. Semester of the Degree in Engineering in Development and Business Innovation of the Technological University of Jalisco:

\footnotetext{
- $\quad$ Katia Nallely Arias Torres

- $\quad$ Alexis Iliana Hernández Guzmán

- $\quad$ Cristian Alejandro López Rodriguez

- $\quad$ Giovana Itzel Loza Velázquez

- $\quad$ Marlen Sinay Melendrez Becerra

- Claudia Carolina Ramírez Velázquez
}

Likewise, the support and facilities granted by the Director of the Administrative Economic Division Karina Guevara Chacón.

\section{Conclusions}

Among the most relevant results for the commercialization of the dental pill, we confirm that $43 \%$ of respondents brush their teeth 3 times a day.

More than $50 \%$ of respondents use Colgate and Oral-B pasta, although they state that the latter is not to their liking.

Respondents pay between 30 and 45 pesos for their toothpaste and buy it once a month, arguing that their purchase decision is based primarily on price, leaving the brand and flavor in the second place.

Most respondents are willing to buy the toothpaste, they would like it to be mint-flavored and willing to pay up to $\$ 50$ for it.

The preferred shopping places for consumers are grocery stores and supermarkets.

The most important thing is that $97 \%$ of respondents agree to buy products that favor environmental care.

\section{References}

INEGI. (2002). Obtenido de https://www.inegi.org.mx/servicios/api_denue.h tml

Namakforoosh, M. N. (2005). Metodologia de la investigación. México: Editorial Limusa, S.A. DE C.V.

Naresh, M. (2012). Investigación de Mercados Un Enfoque Práctico. Prentice Hall. ISBN 9789702611851

Philip, K. (2002). Dirección de Marketing Conceptos Esenciales. 14 ED. Prentice Hall. ISBN 9786073212458 